\title{
Employment patterns of UNAM graduates: an assessment of the employability of the media studies graduates of the University of Namibia
}

\author{
Fred J. Mwilima
}

\section{Introduction}

The Department of Information and Communication Studies of the University of Namibia was established in 1998. Over the years the Department has grown, surpassing expectations to become the flagship of the Faculty of Humanities and Social Sciences in terms of student numbers. This study was carried out in 2009 by the Department of Information and Communication Studies (DICS) and focused on the employment patterns of students who went through its programmes from 2000-2007. The purpose of the study was to obtain feedback from the former students on their current employment, a perspective of their education at the university and what they think may have been missing in their programme which may need to be adjusted to better prepare future students for the job market. Although this study covered graduates of all the programmes in the department, this article will concentrate on graduates of the media studies specialisation (B.A. Media Studies) of the department only.

Background graduate and employer surveys constitute one form of empirical study which can provide valuable information for evaluating the results of the education and training of a specific institution of higher education. Depending on the approach of the tracer study, the institution is able to get information to enable it to identify deficits in its programmes and to serve as a basis for future planning. Data gathered from the former students include the professional success of the graduates and relevance of education and training received. The employers provided valuable information on the methods and criteria of recruitment and on the competencies of the graduates as well as future needs (Schomburg, 2003). An extensive literature review was conducted of related studies in Africa (Kimani, 2002; Kaijage) and other developing countries, as well as developed countries. The literature review focused on methodologies used, results obtained and recommendations made. Studies in this area show that tracer studies are a very reliable way of identifying the impact of programmes offered by institutions of higher learning and provide valuable data on which to base decisions on curriculum development and improvement.

The tracer study which employed the survey method was mostly quantitative. It combined a field survey which was conducted in Windhoek, and an email survey which 
mostly targeted those respondents outside Windhoek and in other countries. The questionnaires were adapted from the ones developed by Schomburg (2003).

2010 Vol 4 (2)

A total of 14 organisations responded to the survey and the economic sectors for the employers ranged from education (36 percent), government (29 percent), NGO (14 percent), private companies ( 7 percent), parastatals ( 7 percent) and other sectors (7 percent); the one indicated other is from the media sector. The organisations participating in the survey indicated that most employed 31 and above employees (54 percent) and 14 percent of them employed between 1 and 10 employees from the Department of Information and Communication Studies. The remainder employed between 21 and 30 employees. Regarding the characteristics of the surveyed graduates, 75 percent were Namibians, 13 percent from SADC and 9 percent from other countries such as Germany and Cuba.

The Department of Information and Communication Studies which was established in 1998, is housed in the Faculty for Humanities and Social Sciences of the University of Namibia. Currently, the Department offers two very popular special degree programmes; Bachelor of Library Science and Bachelor of Arts in Media Studies. The department also offers two-year Diploma programmes in Library Science; Records and Archives Management and Public Relations. These diploma programmes also serve as entry level qualification to other degree programmes in the University. Currently the department has six full-time staff members, one professor, and three staff members at $\mathrm{PhD}$ levels, and one who is in a process to complete her PhD. The department has just recruited a staff development fellow. All six staff members are specialised in the core areas of teaching and research in the programmes offered. The number of local to expatriate staff members in the department stands at 3 to 4.

\section{Teaching and learning}

This has always been and will remain a priority area within the department. The Department recognises the need for regular review of curriculum in line with the envisaged Namibia Qualification Authority (NOA) requirements. The important role of the external examiner right from curriculum review, and examination papers, as well as an advisory committee consisting of various stakeholders takes centre stage in academic activities of the department and serves as an important tool for improvement.

\section{Academic strategy}

The academic strategy of the department borne out of its vision, mission and SWOT Analysis, as well as key performance areas put emphasis on quality, up-to-date-ness, relevance in programmes, increased research output, publications, consultancy output, close collaboration with its social partners and stakeholders, and networking within and beyond the University of Namibia. The following modules are offered by the media section of the Department of Information and Communication Studies:

\section{Table 1: Current modules for B.A. Media Studies}

\section{Year 1} Semester 1 
doi: $10.5789 / 4-2-5$

\begin{tabular}{|c|c|c|}
\hline & & $\begin{array}{l}\text { 1. Contemporary Social issues } \\
\text { 2. Computer literacy } \\
\text { 3. Foundation of Information Studies }\end{array}$ \\
\hline & Semester 2 & \\
\hline & & $\begin{array}{l}\text { 1. English for academic purpose } \\
\text { 2. English communication and study skills } \\
\text { 3. English for general Communication }\end{array}$ \\
\hline & & 4. \\
\hline Year 2 & & \\
\hline & Semester 1 & \\
\hline & & $\begin{array}{l}\text { 1. Desktop Publishing } \\
\text { 2. Media Writing and Reporting } \\
\text { 3. Media laws, Ethics and policy }\end{array}$ \\
\hline & Semester 2 & \\
\hline & & $\begin{array}{l}\text { 1. Rural and Community Reporting } \\
\text { 2. Web development } \\
\text { 3. Specialised Reporting }\end{array}$ \\
\hline Year 3 & & \\
\hline & Semester 1 & \\
\hline & & $\begin{array}{l}\text { 1. Knowledge Management } \\
\text { 2. Investigative Reporting } \\
\text { 3. Media and Information Studies Research } \\
\text { 4. Corporate communication } \\
\text { 5. Broadcast Writing } \\
\text { 6. Advanced Reporting: Magazine } \\
\text { Photojournalism }\end{array}$ \\
\hline & Semester 2 & \\
\hline & Public Relations & $\begin{array}{l}\text { 1. Advertising and Public Relation Campaigns } \\
\text { 2. Integrated Marketing Strategies }\end{array}$ \\
\hline & Electronic media & $\begin{array}{l}\text { 1. Radio Production } \\
\text { 2. Television Production }\end{array}$ \\
\hline & Print media & $\begin{array}{l}\text { 1. Principles and Practice of Newspaper Editing } \\
\text { 2. Specialised Journalism: Sports and Elections }\end{array}$ \\
\hline Year 4 & & \\
\hline & Public Relations & \\
\hline & & 1. Advanced Public Relations and Advertising \\
\hline & Electronic media & \\
\hline & & 2. Advanced Broadcasting \\
\hline & Print media & \\
\hline & & 3. Advanced Print Journalism \\
\hline
\end{tabular}

\section{Objectives}

The objectives of the tracer study were to establish the current employment trends of former graduates of DICS; provide information that will allow assessment of the immediate and long-term value of the programmes, assess the contribution of the 
graduates to industry. The study assesses current trends in labour market requirements for DICS graduates from labour market signals; the graduate's perception of the study

2010 Vol 4 (2)

conditions and provisions while at the university, their transition from higher education to employment from the graduate's perception; identifies the present job status of the graduates and the extent to which their jobs are appropriate to their level of education and determines the extent to which graduates use knowledge, attitudes and skills acquired during their study at the university in their present jobs.

\section{Research methodology}

The quantitative survey method was employed and combined a field and email which targeted those in Namibia and outside Namibia. The instrument of data collection was through the use of questionnaires. Two of such questionnaires were administered: one for former graduates of B.A. Media Studies and the other for employers. A total of 137 graduates were surveyed. Due to lack of employment records, the snowball technique was used to trace graduates. The questionnaires were administered by research assistants who physically distributed the questionnaires. The rest of the questionnaires were sent out through emails to former graduates in other parts of Namibia as well as other countries. The data collected was analysed with the aid of SPSS. All the returned questionnaires were analysed for suitability for further data analysis. The correctly answered questionnaires were coded and the returns entered into Excel files that were later processed using SPSS.

\section{Data analysis \\ Student intake and specialisation}

The two graphs below show the years in which the graduates commenced the study programme and their areas of specialisations. Their academic years spanned from 1999 to 2005. Thirty six percent (36 percent) of the graduates had completed some professional education prior to their studies at the University of Namibia. Only 25 percent of the respondents were employed before they started their studies at the University of Namibia. Of these, the number of years of employment ranged from 1 to eleven years, with an average of four years, and a standard deviation of four years.

The number of students admitted annually fluctuated between 10 percent and 60 percent, with the lowest figures dwindling to 10 percent in 2002. As expected of a new programme, at its beginning in the first two years (1998-1999), only about 10 percent of graduates were admitted to the programme. The next two years, 2000 and 2001, the figures doubled to 40 percent, but again dwindled to its lowest in 2002. The highest intake of the sampled group was in 2004 with about 65 percent intake as shown in the graph below. The majority of students (50 percent) opted for Psychology as the most popular second major, followed by Sociology (21 percent) with Geography/Environmental Studies (five percent) and Political Studies (nine percent). Other second majors were English and Drama. 
Table 2: Years of intake into the programme

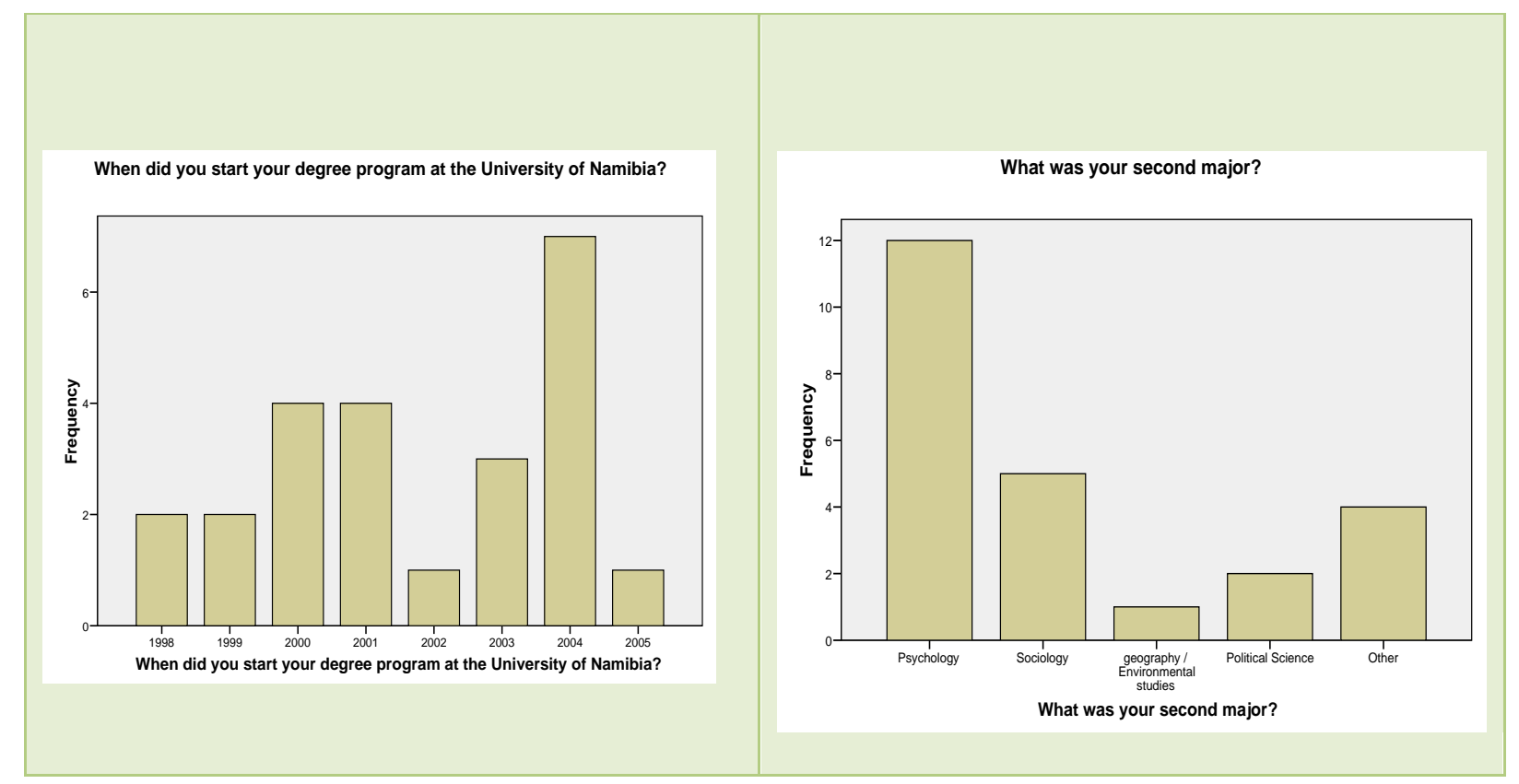

Job search, employment activities and work

A total of 75 percent of the 24 respondents were employed with 21 percent in professional training and 13 percent in further academic studies. About 83 percent of the graduates sought employment after graduation with only eight percent continuing with their previous jobs and the remainder obtained work without actually searching for it. The methods used to seek for employed were applying for advertised vacancies, followed by being approached by the employers by enlisting the assistance of teaching staff and establishing contacts during internships. Some students had applied for as many as 100 times. The average number of applications was 17 with a standard deviation of 29.

Participation in tests and/or auditions ranged from zero to five with a mean of two and a standard deviation of one test/audition. Interview invitations ranged from zero to eight with a mean of three and standard deviation of two interviews. Positions offered ranged from zero to ten with an average of two and a standard deviation of three positions. Most (60 percent) of the graduates were employed within the first five months, twenty within a year and the remainder after a year. The field of study and previous work experiences stood out as the most important aspects as criteria for selection for employment, and to a lesser extent, the main focus of subject areas/specialisation and reputation of the Department or University. 
Table 4: Criteria for used for selection for employment

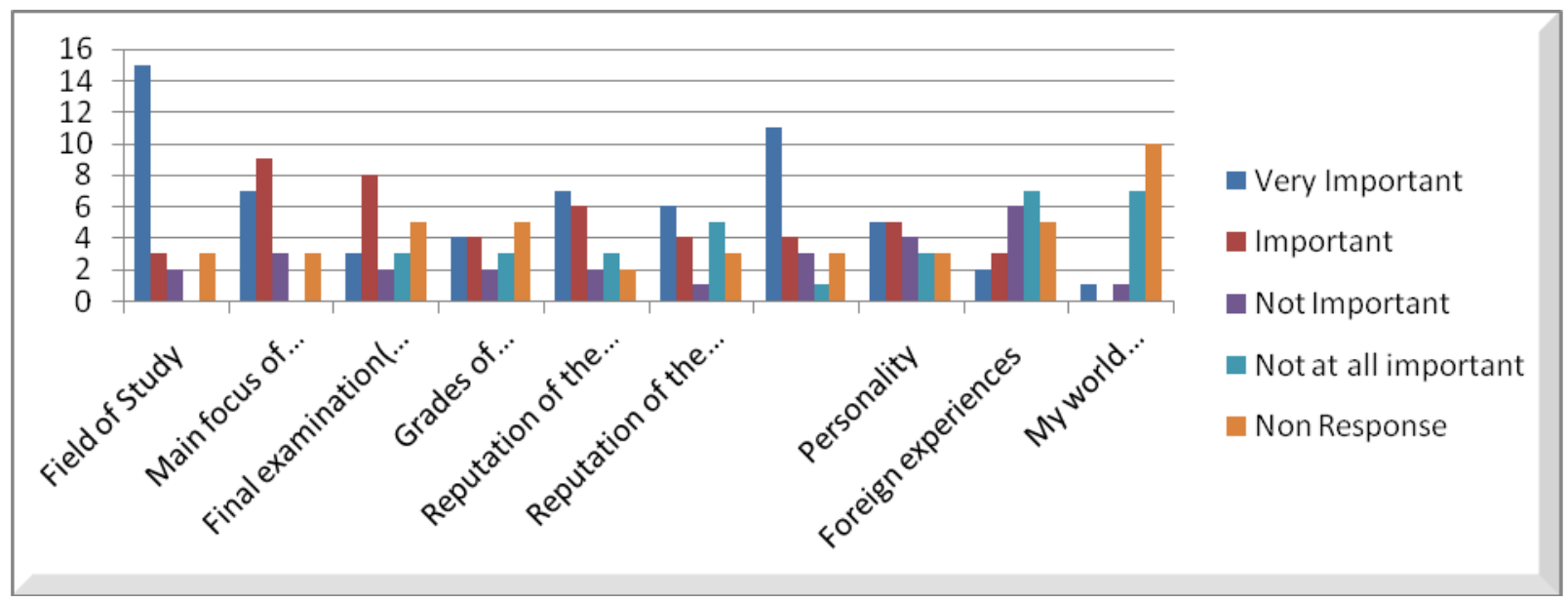

In terms of suitability for employment, employers tended to consider field of study (71 percent), main subject/specialisation (46 percent), recommendations/references from third persons (46 percent), practical work experience acquired prior to study (38 percent), experience abroad (38 percent); and to a lesser extent reputation of the university/department (29 percent). Examination results (17 percent), foreign language proficiency (13 percent) and computer skills (four percent) come much down the line. Of the research sample, 46 percent said the training at UNAM had prepared them for interviews. The aspects of the programme which were cited as having contributed to their preparedness were (1) Communication skills, (2) Interpersonal skills, (3) Journalistic creativity, (4) Behavioural aspects, (5) Interview skills, (6) Industrial psychology and, (7) Public Relations. The graduates were of the opinion that coaching for interviews, presentation skills were not emphasised in the programme.

\section{Predominant activities:}

Most of the graduates (54 percent) spent most of their time on regular jobs and 38 percent of them on temporary jobs. The titles and positions of job activities included Public Relations Officer, Corporate Relations Officer, Private Control Information Officer, Assistant Producer, Radio News and Current Affairs, News Journalist, Corporate Communications Officer/Manager, Information Officer, Administration Assistant, Enumerator, Liaison Officer, Radio Presenter/Technician and Investment Clerk. Most (73 percent) of the graduates have changed their employment since graduation. Of these, 93 percent have had between one to five employers. The reasons for change of employment included better positions ( 46 percent), higher income ( 42 percent), to take over desirable professional tasks (36 percent), use qualifications acquired during studies (33 percent). The length of service with current employers ranged from two to 62 months, with an average of 21 months and standard deviation of 18 months. 
2010 Vol 4 (2)

Table 5: Predominant activities

\begin{tabular}{|l|c|l|l|}
\hline $\begin{array}{l}\text { I have spent most of my time in a } \\
\text { regular job }\end{array}$ & 13 & $\begin{array}{l}\text { I mainly more than one job at the } \\
\text { same time }\end{array}$ & 2 \\
\hline I had various temporary jobs & 9 & I was most of the time unemployed & 3 \\
\hline $\begin{array}{l}\text { I mainly embarked on further studies } \\
\text { or professional training }\end{array}$ & 3 & $\begin{array}{l}\text { I was predominantly engaged in child } \\
\text { rearing or family care }\end{array}$ & 0 \\
\hline Others (volunteer) & 1 & \\
\hline
\end{tabular}

\section{Graduate recommendations:}

One of the objectives of the study was to give opportunity to former graduates to provide the department with information that will allow assessment of the immediate and long-term value of the programmes. In the survey they recommended inclusion of the following into the study programme. This survey covered former students who have gone through the programme between the years 2000 and 2007. In 2007 the department was engaged in stake holder consultations which lasted for one year and whose recommendations were incorporated in the study programmes. Some of the recommendations of the former graduates already form part of curriculum as can be seen in tables 1 and 2 .

Table 6: Graduate recommendations on programme improvement

\begin{tabular}{|l|l|}
\hline TV, Radio and film production & Journalism (both print and electronic) \\
\hline Presentation skills & Photography \\
\hline Media law reforms & Investigative journalism \\
\hline Media monitoring analysis and reform & $\begin{array}{l}\text { More practical and hands on in corporate } \\
\text { world }\end{array}$ \\
\hline Web page design & Report writing \\
\hline Desktop publishing & Events management \\
\hline Interview preparation & Msc in corporate communication \\
\hline
\end{tabular}

\section{Skills at the time of employment:}

Upon joining first employer after completion of studies, there was no training (29 percent), and most help was sought from experienced colleagues (42 percent), and relatively less help sought from superiors (21 percent). Very few (4 percent) had attended any orientation/training programmes. For those that participated in training programmes, 75 percent attended those of one to five months duration while other graduates' programmes lasted more than five months. Most of them (72 percent) felt that they were competent enough to do their work effectively within the first 5 months and believed to have gained new knowledge and skills at the beginning of their employment (see table below). Only 33 percent of the graduates were trained at the beginning of their employment to take over management positions in future. 
Table 7: Knowledge gained within five months

\begin{tabular}{|c|c|c|}
\hline Strategic orientation & Relationship management & Stakeholder communication \\
\hline Events management & Media relationships & Production of materials \\
\hline Internet use & $\begin{array}{ll}\text { Public } & \text { Relations } \\
\text { management } & \end{array}$ & Script Writing \\
\hline $\begin{array}{ll}\text { Interview } & \text { and } \\
\text { presentation skills } & \end{array}$ & $\begin{array}{l}\text { News compilation and } \\
\text { translation }\end{array}$ & Speed and accuracy \\
\hline $\begin{array}{l}\text { Publication and media } \\
\text { relations planning }\end{array}$ & $\begin{array}{l}\text { Data capturing processing } \\
\text { and sharing }\end{array}$ & Report writing \\
\hline Communication skills & $\begin{array}{l}\text { Radio/TV } \\
\text { production } \\
\text { presentations }\end{array}$ & Camera use \\
\hline Text and picture editing & Magazine compilation, & $\begin{array}{l}\text { Exposure to the Banking } \\
\text { sector }\end{array}$ \\
\hline Negotiating skills & Handling Pressure & \\
\hline
\end{tabular}

\section{Retrospective assessment of studies}

Most (54 percent) of the respondents chose to study at the University of Namibia because it is the only university in the country. For others ( 21 percent), it was close to home and 13 percent chose the institution due to the affordability of the programmes offered and only $4 \%$ felt they were compelled to study at Unam due to lack of alternatives. Another reason was that the University of Namibia offered programmes of their choice and that it was in their country. The graduates identified the following as the strengths of the study programme: (1) It has good and competent lecturers; (2) the curriculum is broad and hence covers all parts of the study programme; and (3) the theoretical content is extensive and well covered.

\section{Programme weaknesses}

They also identified the weaknesses in the programmes which they listed as (1) very little practical coverage, (2) lack of lecturers; (3) bad teaching methods; (4) bias towards certain courses at the expense of others, e.g. Journalism leaving out other media specialties such as TV and Radio; and Print Media leaving out Electronic Media; (5) lack of resources like computers, laboratory equipment and materials; and (6) lack of part-time programme. However, much of the weaknesses identified have been have been addressed and included in the new curriculum.

\section{Changes to the degree programme}

Suggestions on changing the degree programme included; practical work 21 (88 percent); computer facilities 15 (63 percent); curriculum research 12 (50 percent); research 11 (46 percent); availability of lecturers 11 (46 percent); other changes which include classroom space, counselling and methods of teaching, 9 (38 percent). Generally the respondents were satisfied with the study provisions which were rated by the majority as being either 
good or very good as shown in the graph below. However their ratings of provision of work placement and other work experiences, contacts with fellow students, practical

emphasis of teaching and learning, chances for students to have impact on University policies, and supply of teaching materials were rather negative. But, the majority of the students perceived the programme to be either very good or good.

\section{Usefulness of study to job placement}

Generally the graduates rated their studies as fairly useful to very useful for job placement, fulfilling present tasks, professional/career development and economic development of their country. Most of the graduates were likely to choose the same course of study (42 percent), choose a higher degree level of higher education (50 percent), and relatively few students (17 percent) would settle for a lower degree level of higher education. Relatively few students (17 percent) would choose the same institution of higher learning.

Table 8: Usefulness of study programme

\begin{tabular}{|l|c|c|c|c|c|c|}
\hline \multicolumn{1}{|c|}{ Usefulness of studies } & $\begin{array}{c}\text { Very } \\
\text { Useful }\end{array}$ & $\begin{array}{c}\text { Use } \\
\text { ful }\end{array}$ & $\begin{array}{c}\text { Fairly } \\
\text { useful }\end{array}$ & $\begin{array}{c}\text { Not } \\
\text { useful }\end{array}$ & $\begin{array}{c}\text { Not at } \\
\text { all } \\
\text { Useful }\end{array}$ & $\begin{array}{c}\text { No } \\
\text { respon } \\
\text { se }\end{array}$ \\
\hline $\begin{array}{l}\text { For finding an adequate job after } \\
\text { finishing studies }\end{array}$ & 6 & 10 & 4 & 0 & 2 & 2 \\
\hline For fulfilling your present tasks & 4 & 7 & 9 & 0 & 2 & 2 \\
\hline $\begin{array}{l}\text { For professional/ career } \\
\text { development }\end{array}$ & 7 & 7 & 5 & 1 & 1 & 3 \\
\hline $\begin{array}{l}\text { For the development of your } \\
\text { personality/education }\end{array}$ & 8 & 8 & 3 & 1 & 1 & 3 \\
\hline $\begin{array}{l}\text { For the economic development of } \\
\text { your country }\end{array}$ & 8 & 8 & 4 & 0 & 1 & 2 \\
\hline
\end{tabular}

\section{Conclusion}

The study shows that despite graduates having gone through various temporary jobs (38 percent), the majority (54 percent) of the graduates have regular employment. Those who opted to further their studies are in the minority (13 percent). The survey also reveals that 93 percent of the employers regarded the field of study as the most important criteria for recruitment selection as they expect the graduates to bring in new skills and knowledge to the organization. 
doi: $10.5789 / 4-2-5$

Issues cited and suggested to be included in the programme were focus on running commercial radio stations, advanced reporting and editing skills in print and audio visual media. The media studies graduates felt the curriculum had a bias towards Journalism at the expense of others

2010 Vol 4 (2)

such as electronic media. The survey also revealed that 60 percent of the graduates were employed within the first five months after graduation.

\section{References}

Al-Samarrai, S. \& Bennell, P. 2006. Where has all the education gone in sub-Saharan Africa? Employment and other outcomes among secondary school and university leavers. Available at: http://mpra.ub.uni-muenchen.de/128/1/MPRA_paper_128.pdf

Association of African Universities and University of Namibia, 2002. Report of the regional workshop on tracer studies of past university students, University of Namibia, 2002-01-11

Kaijage, E. Knowledge and skills of B.Com graduates of the Faculty of Commerce and Management $\left(2^{\text {nd }}\right.$ ed), University of Dar es Salaam in the job market

Kamani, G. 2002. A tracer study of University of Nairobi graduates, 1991 1998. Paper prepared for CODESRIA'S $10^{\text {th }}$ General Assembly on 'Africa in the New Millennium', Kampala, Uganda, 8-12 December 2002

Schomburg, H. Handbook for graduate tracer studies. Bonn: University of Kassel: Centre for Research on Higher Education and Work

Five year development plan 2006-2010, Department of Information and Communication Studies, University of Namibia

Faculty year book 2010. Prospectus for the Faculty of Humanities and Social Sciences, University of Namibia 